\title{
Penicillin encephalopathy
}

\author{
N. Conway \\ M.B., M.R.C.P.
}

\author{
E. BECK \\ M.B., B.Sc., M.R.C.P.
}

\author{
JANE SOMERVILLE \\ M.D., M.R.C.P. \\ The National Heart Hospital and Whittington Hospital, \\ London
}

\section{Summary}

Five patients who developed characteristic myoclonic twitching, drowsiness and convulsions due to intravenous penicillin and cloxacillin are described. Three had poor renal function. Twenty-three reported cases of penicillin encephalopathy are reviewed and the aetiology of the syndrome is discussed.

\section{Introduction}

In 1947 Reuling \& Cramer reported that intrathecal penicillin could cause convulsions, but as penicillin crosses the blood-brain barrier with difficulty, convulsions are not expected with intramuscular or intravenous administration. In recent years, however, penicillin has been given in large amounts intravenously for the treatment of certain bacterial infections and neurotoxicity has been reported. A further five cases are described.

\section{Case 1}

A 36-year-old man with severe rheumatic mitral and aortic incompetence had both valves replaced by a combined homograft by Mr D. N. Ross in the National Heart Hospital on 5 September 1966. Following operation bacterial endocarditis was suspected. Cloxacillin $2 \mathrm{~g}$ daily and streptomycin $1 \mathrm{~g}$ intramuscularly were stopped and blood cultures were taken. No organism was obtained, but the fever persisted. At this time the blood urea was $13 \mathrm{mg} / 100 \mathrm{ml}$. Two weeks after operation penicillin 50 megaunits and streptomycin $1 \mathrm{~g}$ daily were started by continuous intravenous infusion. The fever continued and ampicillin $4 \mathrm{~g}$ daily was added a week later. On the 26th post-operative day the blood levels of ampicillin and penicillin were only $10 \mu \mathrm{g} / \mathrm{ml}$ so probenecid $2 \mathrm{~g}$ daily was added. On the 35th day after operation the blood level of penicillin was $200-250 \mu \mathrm{g} / \mathrm{ml}$ and that of ampicillin was $35 \mu \mathrm{g} / \mathrm{ml}$. In spite of this, the fever continued and cephaloridine $8 \mathrm{~g}$ and cloxacillin $12 \mathrm{~g}$ daily were substituted for ampicillin. Clinical improvement followed, but in view of increasing mitral incompetence the patient's heart was re-explored on 31 October, 8 weeks after the first operation. The aortic homograft was intact, but several mitral chordae had ruptured. No vegetations were seen. The mitral valve was replaced with a Starr-Edwards prosthesis and after this second procedure the patient was kept on intravenous penicillin 60 mega-units, cloxacillin $12 \mathrm{~g}$, cephaloridine $8 \mathrm{~g}$ and streptomycin $1 \mathrm{~g}$ daily. Full consciousness was regained. The blood urea was $50 \mathrm{mg} / 100 \mathrm{ml}$.

On the 3rd day after the second operation, three grand mal fits occurred. Bilateral spasticity and extensor plantar responses were present but there were no localizing signs in the central nervous system. Anti-convulsant therapy was started, but on the 4th post-operative day the patient was drowsy and had developed generalized coarse muscular twitching. The blood levels on this day were: urea, $115 \mathrm{mg} / 100 \mathrm{ml}$, penicillin $177 \mu \mathrm{g} / \mathrm{ml}$, and cephaloridine $106 \mu \mathrm{g} / \mathrm{ml}$. Penicillin toxicity was suspected and the daily dose was reduced to 15 mega-units leaving the dosage of the other drugs unaltered. The myoclonic twitching disappeared, but he remained drowsy. On the 5th day the blood level of penicillin was $122 \mu \mathrm{g} / \mathrm{ml}$ and of cephaloridine $140 \mu \mathrm{g} / \mathrm{ml}$. The patient's condition deteriorated with hypotension and declining urine output, and the blood urea rose to $295 \mathrm{mg} / 100 \mathrm{ml}$. Despite peritoneal dialysis he died on the 9th postoperative day. The post-mortem showed scattered petachiae throughout the brain. Infarction was present in both kidneys.

\section{Case 2}

A 30-year-old housewife was admitted to the Whittington Hospital on 15 June 1966, with a 3 months' history of malaise, weight-loss and low 
grade fever. For the previous week she had noticed numbness of the right side of the body and on examination she was found to have a mild right hemiparesis. Her pulse was regular but the left brachial and radial pulses were weak. Apical murmurs suggested mitral incompetence and a provisional diagnosis of bacterial endocarditis was made. Soluble penicillin 1 mega-unit intramuscularly every $6 \mathrm{hr}$ was started. Seven blood cultures were negative and 2 days later the patient was transferred to the Neurosurgical Unit for exclusion of a cerebral abscess. Soluble penicillin 100 mega-units in $24 \mathrm{hr}$ was then started by continuous intravenous infusion. Within $36 \mathrm{hr}$ coarse, shaking movements of both arms and legs and twitching of the corners of the mouth and fingers developed. The patient was agitated and dysphasic, but there was no change in the central nervous system. Lumbar puncture showed that the CSF contained protein $90 \mathrm{mg} / \mathrm{ml}$ and 72 white blood cells. A left carotid angiogram was normal. These findings were thought to be consistent with recent cerebral embolism. The myoclonic movements were suppressed with difficulty by intravenous anti-convulsants. The dose of penicillin was not reduced and during the next 3 weeks the patient required large amounts of anti-convulsants to control the myoclonic jerks. Drowsiness, which persisted, was attributed to the medication. On 4 July the dose of penicillin was reduced to 12 mega-units daily by intramuscular injection and cephaloridine $2 \mathrm{~g}$ daily was added. Within $24 \mathrm{hr}$ the twitching stopped and the patient's cerebral state improved.
On 23 July the preparation of penicillin was changed to procaine penicillin 6 mega-units with probenecid $1 \mathrm{~g}$ daily. Four days later another mild episode of myoclonus occurred. Antibiotic treatment was stopped after a further 3 weeks. The patient recovered fully. The blood urea was repeatedly estimated throughout her illness and ranged from 10 to $25 \mathrm{mg} / 100 \mathrm{ml}$.

\section{Case 3}

A woman of 62 years with rheumatoid arthritis and Felty's syndrome was admitted to the Whittington Hospital in September 1966, with painful joints, a serous pleural effusion, and numerous superficial staphylococcal infections in the skin. A soft systolic murmur was audible at the apex, but repeated blood cultures were sterile and there was no laboratory evidence of disseminated lupus erythematosus. The blood urea was $20 \mathrm{mg} / 100 \mathrm{ml}$. Various broad-spectrum antibiotics were given without clinical improvement. The fever persisted and the murmur altered in character so that bacterial endocarditis was suspected. Eleven weeks after admission penicillin 50 mega-units daily was started by continuous intravenous infusion. Three days later generalized myoclonic movements occurred accompanied by confusion and stupor. No localizing signs were found in the nervous system. An electroencephalogram showed a poorly formed alpha rhythm mixed with intermediate slow activity and slow waves diffusely distributed without evidence of a focal lesion (Fig. 1). Penicillin

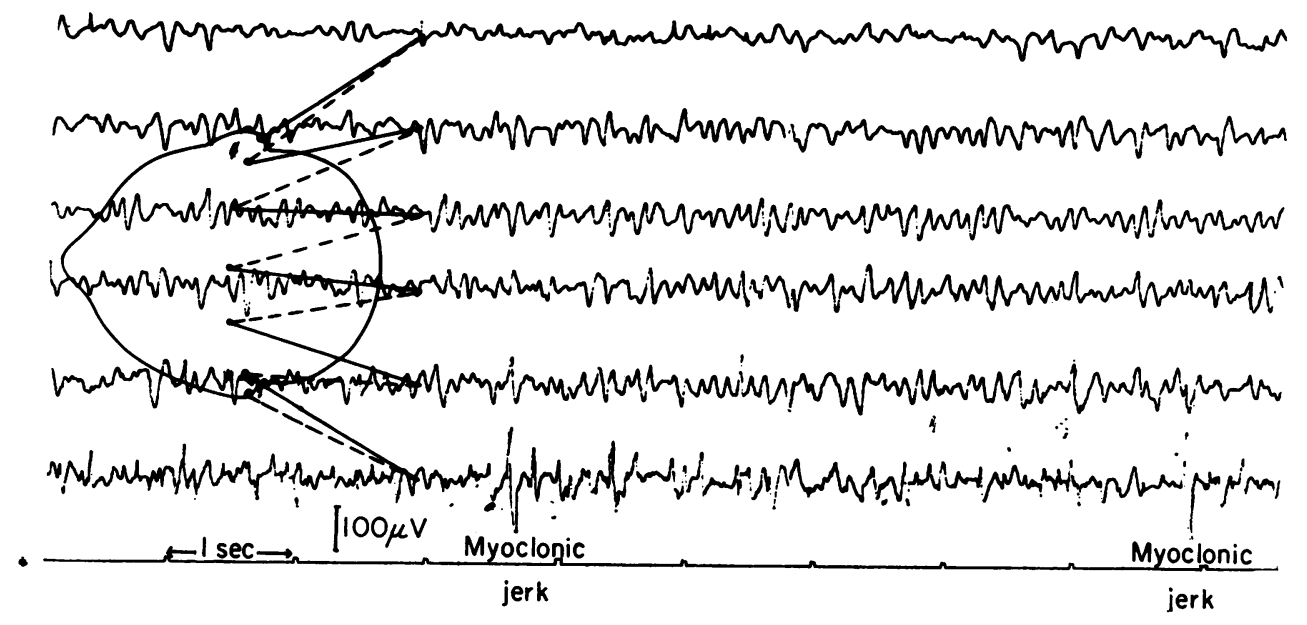

FIG. 1. EEG (transverse intermastoid montage) of Case 3 taken $8 \mathrm{hr}$ after the onset of generalized, including facial, myoclonus, immediately after cessation of penicillin infusion. Diffuse slow wave activity and two myoclonic shocks arising in the left temporalis muscle are shown. 
toxicity was diagnosed and the infusion was stopped. The myoclonic twitching stopped within a few hours but the patient's mental state did not improve. The urine output remained good. Two days later she died suddenly. Autopsy showed a massive pulmonary embolism but revealed no abnormality in the brain or kidneys. No valve lesion was present in the heart.

\section{Case 4}

A 49-year-old man with severe mitral stenosis had a cerebral embolus with a transient hemiplegia. Mitral valvotomy was performed 7 months later by Sir Thomas Holmes Sellors in the National Heart Hospital on 28 July 1966, and 2 days later fever with rigors started. Blood cultures grew Staphylococcus albus which was resistant to penicillin. Cloxacillin $12 \mathrm{~g}$ daily was started on the 8th post-operative day by intermittent intravenous injection. The fever continued and the dose of cloxacillin was increased to $18 \mathrm{~g}$ daily on the 11 th day after operation. At this time the blood urea was $31 \mathrm{mg} / 100 \mathrm{ml}$. Signs of heart failure appeared and frusemide $80 \mathrm{mg}$ was given on alternate days. On the 15th day cephaloridine $2 \mathrm{~g}$ daily was added. The blood urea rose to $61 \mathrm{mg} / 100 \mathrm{ml}$ and the urine contained a trace of protein with white cells and casts, but the cultures were sterile. His condition deteriorated and he declined into a severe low cardiac output state with subnormal temperature, oliguria and uraemia. On 18 August he developed myoclonic twitching and drowsiness which was initially attributed to uraemia. The blood urea was $190 \mathrm{mg} / 100 \mathrm{ml}$ and had been $150 \mathrm{mg} / 100 \mathrm{ml}$ on the previous day. Blood was sent for estimation of the cloxacillin level, but it could not be accurately estimated; the blood cephaloridine level was between 100 and 150 $\mu \mathrm{g} / \mathrm{ml}$. Cloxacillin was reduced to $2 \mathrm{~g}$ daily and the cephaloridine was stopped. The twitching stopped within $8 \mathrm{hr}$, but the following day the blood urea had risen further to $235 \mathrm{mg} / 100 \mathrm{ml}$ and the urinary output was $100 \mathrm{ml}$ in $24 \mathrm{hr}$. Arrangements were made for renal dialysis, but the patient died from a sudden attack of acute pulmonary oedema. Post mortem showed a calcified stenosed mitral valve with an orifice of $1 \mathrm{~cm}^{2}$. The orifice was completely covered by a large mass of ante-mortem thrombus attached to the lateral part of the anterior cusp. Old infarction was present in the right cerebral hemisphere and there was infarction of the left corpus striatum. Small recent infarcts were present in the right kidney. The histology of the kidneys and brain was not examined.

\section{Case 5}

In May 1965, a 55-year-old man with mitral stenosis developed mitral regurgitation and bacterial endocarditis was diagnosed. One blood culture grew Streptococcus viridans. Penicillin, 32 mega-units daily, was given intravenously for 7 weeks and the blood urea varied between 25 and $41 \mathrm{mg} / 100 \mathrm{ml}$ during this admission. In the following year anaemia, a raised sedimentation rate and splenomegaly persisted and the urine contained protein and red cells. The mitral regurgitation increased and it was considered that the endocarditis had not been cured, although repeated blood cultures were sterile. The blood urea had risen to $55 \mathrm{mg} / 100 \mathrm{ml}$ and an intravenous pyelogram showed scarring of the left kidney. Renal biopsy suggested the presence of chronic pyelonephritis. Severe mitral regurgitation was confirmed by cardiac catheterization and mitral valve replacement was advised. At operation by Mr D. N. Ross on 12 August 1966, active bacterial endocarditis was found on the mitral valve, which was excised and replaced with a mitral homograft. Following this operation the patient was treated with daily penicillin 40 mega-units, cloxacillin $12 \mathrm{~g}$ and streptomycin $1 \mathrm{~g}$, given by continuous intravenous infusion. On the 1st post-operative day he developed a grand mal convulsion and coma at a time when the blood urea was $66 \mathrm{mg} / 100 \mathrm{ml}$. Anticonvulsant drugs were started, and the patient recovered consciousness, but 9 days later he became drowsy and confused with generalized myoclonic muscular twitching. At this time the blood urea was $115 \mathrm{mg} / 100 \mathrm{ml}$. Antibiotic toxicity was suspected and all three were stopped for $6 \mathrm{hr}$, and then resumed at a lower dosage of penicillin 15 mega-units, cloxacillin $4 \mathrm{~g}$ and streptomycin $1 \mathrm{~g}$ daily. The twitching and confusion disappeared although the blood urea rose further. Blood levels of penicillin and cloxacillin declined at first, but the penicillin level rose again later (Table 1). Ampicillin, $8 \mathrm{~g}$ daily, was added on the 11th day and in spite of high blood levels of penicillin the neurological symptoms did not recur. The blood urea progressively fell to normal levels. After 5 weeks, antibiotics were stopped but the high fever reappeared. There was no evidence of mitral regurgitation. Over succeeding weeks attempts to recover an organism failed and culture of vegetations on the excised valve was sterile. No other cause for the fever was found so a second course of penicillin 12 mega-units, cephaloridine $8 \mathrm{~g}$ and streptomycin $1 \mathrm{~g}$ daily was started by continuous intravenous infusion. The fever subsided but did not disappear. In view of the normal blood 
TABLE 1

Case 5: details of antibiotic dosage, antibiotic blood levels, blood urea and penicillin encephalopathy

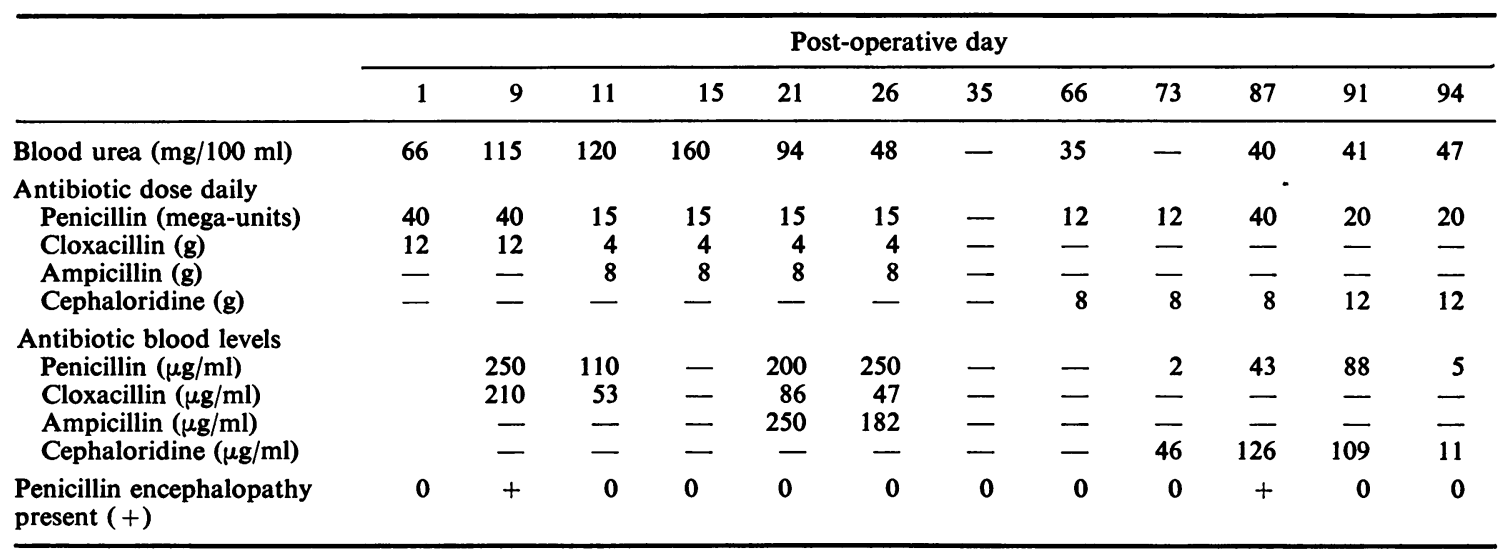

urea and the low antibiotic blood levels (Table 1), the dose of antibiotics was increased to penicillin, 40 mega-units, cephaloridine $12 \mathrm{~g}$ and streptomycin $1 \mathrm{~g}$ daily. Over the next 4 days mental confusion, drowsiness and myoclonic movements recurred. No focal signs were found in the nervous system and once again a reduction of penicillin dosage to 20 mega-units daily was followed by disappearance of twitching and drowsiness within $24 \mathrm{hr}$. On the 100th day after operation the patient developed agranulocytosis. At this stage positive serological tests for $R$. burnetti were received. The patient died on the 105 th day. At autopsy massive vegetations of Candida albicans endocarditis were discovered.
The brain was normal and minor pyelonephritic changes were present in both kidneys.

\section{Discussion}

Encephalopathy following massive intravenous penicillin administration has been recognized since 1952 (Bateman et al.). Since then, another $\stackrel{\mathbb{Q}}{2}$ eighteen cases have been added (Weinstein, Lerner \& Chew, 1964; New \& Wells, 1965 ; Dobell et al., 1966; Oldstone \& Nelson, 1966 ;0 Clinico-pathological Conference, 1967; Smith, Lerner \& Weinstein, 1967; Bloomer, Barton \& Maddock, 1967 ; Cohill et al., 1967). Clinical details of these twenty-three cases are summarized in Table 2. The five patients in this

TABLE 2

Clinical details of twenty-three reported cases of penicillin encephalopathy

\begin{tabular}{|c|c|c|c|c|c|c|c|c|c|c|}
\hline $\begin{array}{l}\text { Case } \\
\text { No. }\end{array}$ & Author & $\begin{array}{l}\text { Age } \\
(\mathrm{yr})\end{array}$ & Sex & $\begin{array}{c}\text { Disease being } \\
\text { treated with } \\
\text { penicillin }\end{array}$ & $\begin{array}{c}\text { Dose of } \\
\text { penicillin } \\
\text { at time of } \\
\text { encephalo- } \\
\text { pathy } \\
\text { (mega-units) }\end{array}$ & $\begin{array}{l}\text { Duration of } \\
\text { treatment } \\
\text { before } \\
\text { onset of } \\
\text { encephalo- } \\
\text { pathy }\end{array}$ & $\begin{array}{l}\text { Highest } \\
\text { blood } \\
\text { urea } \\
(\mathrm{mg} / \\
100 \mathrm{ml})\end{array}$ & $\begin{array}{l}\text { Serum } \\
\text { sodium } \\
(\mathrm{mEq} / \mathrm{l})\end{array}$ & $\begin{array}{l}\text { Penicillin } \\
\text { stopped (S) } \\
\text { reduced } \\
\text { (R) or } \\
\text { continued } \\
\text { (C) }\end{array}$ & Outcome \\
\hline & $\begin{array}{l}\text { Bateman et al. } \\
\text { (1952) }\end{array}$ & 52 & $\mathbf{F}$ & Carcinomatosis & $\begin{array}{l}36 \\
\text { (in } 8 \mathrm{hr} \text { ) }\end{array}$ & $8 \mathrm{hr}$ & 83 & 146 & $\mathbf{S}$ & $\begin{array}{l}\text { No further convulsions. } \\
\text { Died } 9 \text { days later of } \\
\text { carcinomatosis }\end{array}$ \\
\hline 2 & $\begin{array}{l}\text { Weinstein } \\
\text { et al. (1964) }\end{array}$ & 12 & $\mathbf{M}$ & $\begin{array}{l}\text { Gram-negative } \\
\text { pyelonephritis }\end{array}$ & $\begin{array}{l}40 \\
\text { (daily) }\end{array}$ & 7 days & 'Uraemia' & - & $\mathbf{R}$ & $\begin{array}{l}\text { Reduced to } 4 \text { mega- } \\
\text { units daily. Recovered }\end{array}$ \\
\hline 3 & $\begin{array}{l}\text { Weinstein } \\
\text { et al. (1964) }\end{array}$ & 67 & $\mathbf{M}$ & $\begin{array}{l}\text { Post-operative } \\
\text { fever }\end{array}$ & $\begin{array}{l}80 \\
\text { (daily }\end{array}$ & $24 \mathrm{hr}$ & 32 & - & $\mathbf{S}$ & $\begin{array}{l}\text { Myoclonus stopped } \\
\text { after } 12 \mathrm{hr} \text {, coma per- } \\
\text { sisted. Died after } 48 \mathrm{hr}\end{array}$ \\
\hline & $\begin{array}{l}\text { New \& Wells } \\
\text { (1965) }\end{array}$ & 50 & $\mathbf{F}$ & $\begin{array}{l}\text { Perinephric } \\
\text { abscess }\end{array}$ & $\begin{array}{l}60 \\
\text { (daily) }\end{array}$ & $24 \mathrm{hr}$ & 43 & 133 & $\mathbf{S}$ & $\begin{array}{l}\text { Myoclonus stopped } \\
\text { after } 72 \text { hr. Recovered. } \\
\text { Later, Penicillin } 6 \\
\text { mega-units given with- } \\
\text { out ill effect }\end{array}$ \\
\hline
\end{tabular}


TABLE 2-Continued

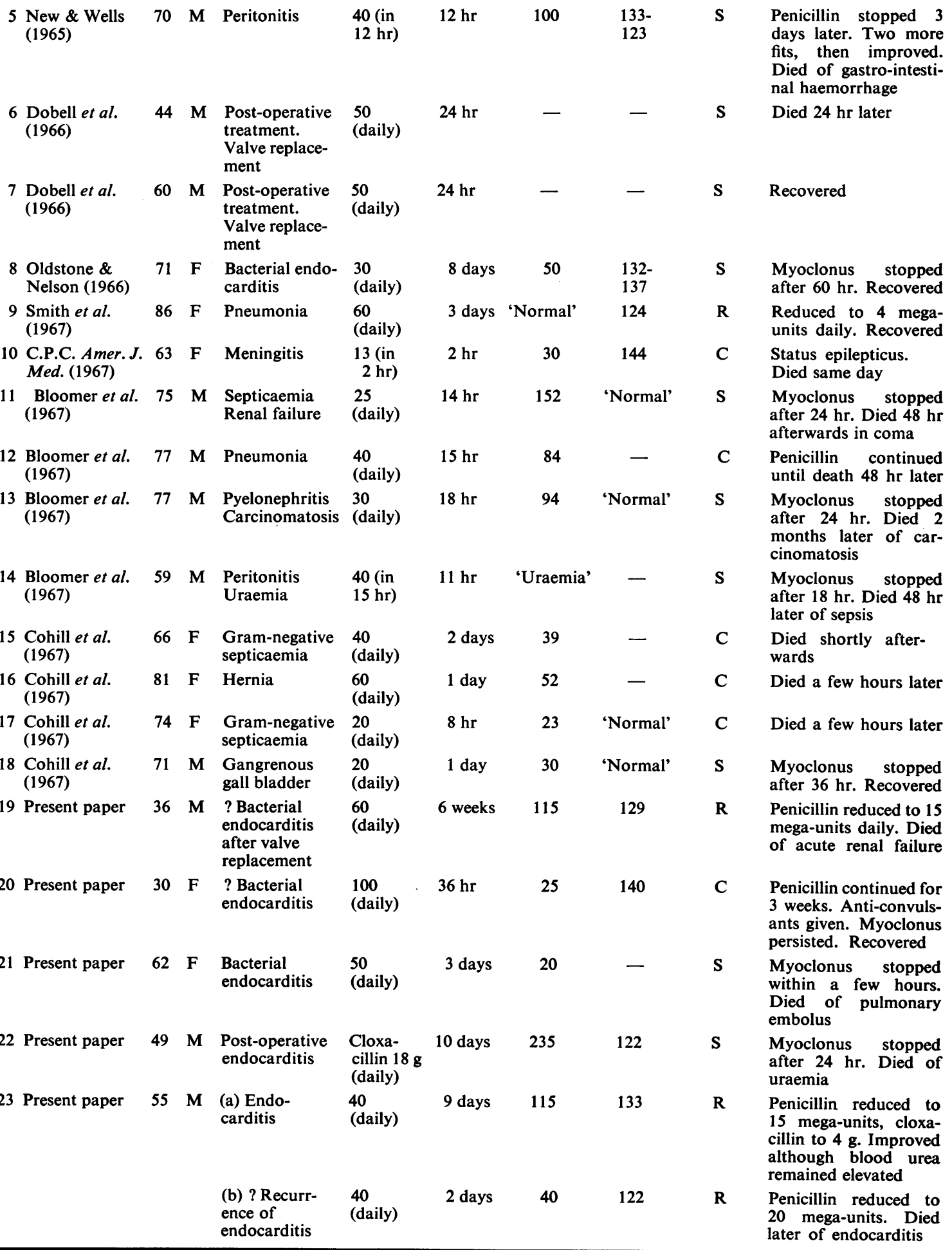


report show the characteristic features of penicillin encephalopathy, namely the combination of drowsiness, confusion, occasional hallucinations and generalized myoclonic jerking movements which may progress to convulsions and coma. Sometimes, as in Case 1, convulsions occur without warning. No focal signs appear in the nervous system and the cerebro-spinal fluid, when examined, has been found to be clear and under normal pressure. The abnormalities found in the CSF in Case 2 were attributed to the presence of intracerebral pathology. The electroencephalogram has been reported to show diffuse abnormality (New \& Wells, 1965; Oldstone \& Nelson, 1966) such as was found in Case 3.

The encephalopathy appears to be associated with toxic concentrations of penicillin reaching the CSF and the brain (Smith et al., 1967). This appears to be a direct result of a high blood concentration of penicillin, alone or in combination with increased permeability of the bloodbrain barrier. In every case the daily dose of penicillin has exceeded 20 mega-units. Fishman (1964) has suggested that persistently high penicillin levels from continuous intravenous administration have time to penetrate the bloodbrain barrier whereas the transiently raised blood concentrations from intermittent dosage are excreted before they can cross it. Both methods of administration have, however, been employed in the twenty-three reported cases.

Apart from the high blood level of penicillin, other factors must influence the appearance of the encephalopathy. For example, in Case 1 the blood penicillin concentration at the time of the onset of toxic symptoms was lower than 3 weeks previously when there had been no sign of neurotoxicity. Clearly, the permeability of the bloodbrain barrier is most important and is known to increase in meningitis (Dobbing, 1961), in uraemia (Freeman, Maher \& Schrimer, 1962) and after cardio-pulmonary by-pass (Dobell et al., 1966).

Uraemia appeared to be a precipitating factor in three of our patients, as in many of the previously reported cases. Penicillin is normally excreted by the kidney and impaired renal function, therefore, causes progressive accumulation of this drug in the body (Cannon et al., 1951). This may explain why large doses of penicillin were initially well tolerated in Cases 1, 4 and 5, before renal function had deteriorated. Significantly, eighteen of the twenty-three patients so far described (Table 2) were over 50 years old, which may be related to the reduction in renal efficiency which occurs with age (Davies \& Shock, 1950). In some of these patients, more- over, renal function may well have been impaired for other reasons such as a restricted cardiac output, drugs like cephaloridine and the renal complications of bacterial endocarditis.

There seems little doubt that penicillin is the true cause of this encephalopathy. Other hypotheses, such as uraemia, cerebral emboli, penicillin hypersensitivity, and sodium overload (from intravenous fluids and sodium penicillin) do not fit the clinical facts. Hyponatraemia was present in several patients but the encephalopathy does not appear to be associated with over-hydration. The timing of the onset of symptoms, after penicillin in high dosage has been started, seems to be variable. This can probably be explained by differing rates of accumulation of penicillin within the brain, by alteration in the permeability of the blood-brain barrier, or by changes in renal function. Thus, our first patient tolerated large doses of antibiotics for several weeks but developed neurotoxic symptoms shortly after cardio-pulmonary by-pass at a time when the blood urea had risen above normal. In every case where penicillin has been stopped or reduced considerable clinical im. provement has occurred and fourteen of the twenty-three reported cases recovered from the encephalopathy.

Our fifth case indicates that there is still much to be learned about the aetiology of penicillin encephalopathy. This patient's story is remark able because he had two episodes of neuro? toxicity due to penicillin. On the first occasion deteriorating renal function was the immediate cause, but it is interesting that reduction in penicillin and cloxacillin dosage abolished his symptoms even though the blood urea rose further. Later, the concentration of three penicillins in the blood rose again to what should have been toxic levels, judging by earlier figures, yet encephalopathy did not recur. The second episode followed equally large penicillin dosage (40 mega-units daily), this time together with ampicillin in large amounts. On this occasion the blood urea was normal and the concentrations of the two penicillins relatively low, but the neurological picture was identical with the first episode. The explanation for these events is obscure, but it is conceivable that penicillin had been retained in the brain from the earlier encephalopathy and that another rise in blood penicillin concentration had caused more to cross the blood-brain barrier. Again, in Case 2, myoclonus returned transiently 4 days after the dose of penicillin was reduced. At this point procaine penicillin and probenecid were being given and it is possible that this combination 
caused further retention of penicillin at a time when its concentration in the brain was still high.

The type of penicillin administered does not appear to be important and both sodium and potassium penicillin have caused neurotoxicity. Two of our patients were given cloxacillin, ampicillin or cephaloridine as well and these drugs may well have contributed to the encephalopathy. The fourth patient received only cloxacillin and cephaloridine and it is likely, therefore, that the new penicillins carry the same neurotoxic risk as penicillin itself.

Cerebral problems are not uncommon in the clinical circumstances in which massive doses of the penicillin group of antibiotics are employed, e.g. septicaemia, bacterial endocarditis and following valve replacement. The possibility of penicillin toxicity as a cause of cerebral symptoms should always be considered, particularly if the characteristic myoclonic movements are present. Co-existent uraemia should not cause confusion if its role in the aetiology of penicillin encephalopathy is appreciated. Renal function must be carefully watched in any patient on massive intravenous penicillin therapy, as it may be necessary to reduce the dose if a rise in blood urea occurs.

\section{Acknowledgments}

We wish to record our gratitude to Dr P. Croydon and Beecham's Laboratories who provided an immediate service for the estimation of blood antibiotic levels, gave us helpful advice and showed a constant interest in our problems. We thank Dr W. Brigden, Dr R. Emanuel, Dr A. L. Jacobs, Dr T. St M. Norris, Mr Donald Ross and Sir Thomas Holmes Sellors for allowing us to publish these cases. We are grateful to Professor Reginald Hudson who gave us some information on the morbid anatomy.

\section{References}

Bateman, J.C., Barberio, J.R., Grice, P., Klopp, C.T. \& Pierpont, H. (1952) Fatal complications of intensive antibiotic therapy in patients with neoplastic disease. Arch. intern. Med. 90, 763.

Bloomer, H.A., Barton, L.J. \& Maddock, R.K. (1967) Penicillin induced encephalopathy in uraemic patients. J. Amer. med. Ass. 200, 131.

Cannon, A.B., Slatkin, M.H., Chester, B. \& Moses, R. (1951) Penicillin level in blood. Significance of type of preparation, dosage, kidney function and weight. J. Amer. med. Ass. 145, 1031.

Chinico-Pathologic Conference (1967) A sixty-three year old woman with fulminant meningitis and convulsions. Amer. J. Med. 42, 264.

Cohill, D.F., Pezzi, P.J., Greenberg, S.R. \& Frobere, A.S. (1967) Central nervous system toxicity secondary to massive doses of penicillin in the treatment of overwhelming infections. Amer. J. med. Sci. 254, 692.

Davies, D.F. \& Shock, N.W. (1950) Age change in glomerular filtration rate, effective renal plasma flow and tubular excretory capacity in adult males. $J$. clin. Invest. 29, 496.

Dobing, J. (1961) The blood brain barrier. Physiol. Rev. 41, 130.

Dobell, A.R.C., Wyant, J.D., Seamens, K.B. \& Gloor, M.D. (1966) Penicillin epilepsy. Studies on the blood brain barrier during cardio-pulmonary by-pass. J. thorac. cardiovasc. Surg. 52, 469.

FishmaN, R.A. (1964) Active transport and the blood brain barrier to penicillin and related organic acids. Trans. Amer. Neurol. Ass. 89, 51.

Freeman, R.B., Maher, J.F. \& Schrimer, G.E. (1962) The blood cerebrospinal fluid barrier in uraemia. Ann. intern. Med. 56, 233.

New, P.S. \& Wells, C.E. (1965) Cerebral toxicity associated with massive intravenous penicillin therapy, Neurology, 15, 1053.

Oldstone, M.B.A. \& Nelson, E. (1966) Central nervous system manifestations of penicillin toxicity in man. Neurology, 16, 693.

Reuling, J. \& Cramer, C. (1947) Intrathecal penicillin. J. Amer. med. Ass. 134, 16.

Smith, H., Lerner, P.I. \& Weinstein, L. (1967) Neurotoxicity and massive intravenous therapy with penicillin. Arch. intern. Med. 120, 47.

Weinstein, L., LeRner, P.I. \& CheW, W.H. (1964) Clinical and bacteriological studies of the effect of massive doses of penicillin $G$ on infections caused by Gram negative bacilli. New Engl. J. Med. 27, 525. 